\title{
Trends in Methadone Distribution for Pain Treatment, Methadone Diversion, and Overdose Deaths — United States, 2002-2014
}

\author{
Christopher M. Jones, PharmD ${ }^{1}$; Grant T. Baldwin, $\mathrm{PhD}^{2}$; Teresa Manocchio, MA ${ }^{1}$; Jessica O. White, MPP ${ }^{1}$; Karin A. Mack, $\mathrm{PhD}^{3}$
}

Use of the prescription opioid methadone for treatment of pain, as opposed to treatment of opioid use disorder (e.g., addiction), has been identified as a contributor to the U.S. opioid overdose epidemic. Although methadone accounted for only $2 \%$ of opioid prescriptions in 2009 (1), it was involved in approximately 30\% of overdose deaths. Beginning with 2006 warnings from the Food and Drug Administration (FDA), efforts to reduce methadone use for pain have accelerated $(2,3)$. The Office of the Assistant Secretary for Planning and Evaluation of the U.S. Department of Health and Human Services and CDC analyzed methadone distribution, reports of diversion (the transfer of legally manufactured methadone into illegal markets), and overdose deaths during 2002-2014. On average, the rate of grams of methadone distributed increased $25.1 \%$ per year during 2002-2006 and declined $3.2 \%$ per year during 2006-2013. Methadone-involved overdose deaths increased $22.1 \%$ per year during 2002-2006 and then declined 6.5\% per year during 2006-2014. During 2002-2006, rates of methadone diversion increased $24.3 \%$ per year; during 2006-2009, the rate increased at a slower rate, and after 2009, the rate declined $12.8 \%$ per year through 2014 . Across sex, most age groups, racial/ethnic populations, and U.S. Census regions, the methadone overdose death rate peaked during 2005-2007 and declined in subsequent years. There was no change among persons aged $\geq 65$ years, and among persons aged 55-64 years the methadone overdose death rate continued to increase through 2014. Additional clinical and public health policy changes are needed to reduce harm associated with methadone use for pain, especially among persons aged $\geq 55$ years.

To identify methadone-related deaths, information was obtained from the 2002-2014 National Vital Statistics System multiple cause of death mortality data (4). Methadone-related deaths were defined as those with an underlying cause of death classified by the International Classification of Diseases, 10th Revision (ICD-10) external cause of injury codes as X40-X44, X60-X64, X85, or Y10-Y14 and ICD-10 code T40.3 for methadone poisoning. Methadone could be listed alone or in combination with other drugs. Age-adjusted death rates were calculated by applying age-specific death rates to the 2000 U.S. standard population age distribution.

Methadone distribution in grams for 2002-2013 was obtained from the Drug Enforcement Administration (DEA) Automation of Reports and Consolidated Orders System.*

\footnotetext{
*http://www.deadiversion.usdoj.gov/arcos/index.html.
}

To limit the analysis to methadone used for pain treatment, methadone distributed to opioid treatment programs was excluded. Data on 2002-2014 reports of methadone diversion, determined through forensic laboratory testing of substances associated with drug cases obtained in federal, state, and local law enforcement operations, were obtained from DEA's National Forensic Laboratory Information System. ${ }^{\dagger}$ Annual counts of methadone diversion reports, and rates per 100,000 population were calculated nationally and by U.S. Census region for 2002-2014. Counts and rates per 100,000 population for methadone overdose deaths were calculated annually, by sex, age group, race/ethnicity, and U.S. Census region for the period 2002-2014. Grams of methadone distributed each year, and rates per 100 population were calculated nationally and by U.S. Census region for 2002-2013.

Joinpoint regression was used to examine changes in trends in rates over time. ${ }^{\S}$ Joinpoint models annual trend data by fitting an exponential curve (i.e., zero joinpoints or no annual percentage change); then adding joinpoints, one at a time, and using a Monte Carlo permutation test to determine the optimal number of joinpoints. In the final model, each joinpoint indicates a statistically significant increase or decrease in trend, and each of these trends is described by an annual percentage change, which represents the average percentage change per year between each joinpoint. For all analyses, a p-value of $<0.05$ was considered to be statistically significant. The Pearson correlation coefficient $(r)$ was used to assess correlation between the methadone distribution rate and rates of methadone diversion and overdose deaths.

During 2002-2006, the national methadone distribution rate increased, on average, $25.1 \%$ per year, and during 2006-2013, declined, on average, $3.2 \%$ per year (Figure 1 ). The methadone overdose death rate increased, on average, $22.1 \%$ per year through 2006. After 2006, the overdose death rate declined, on average, $6.5 \%$ in each subsequent year. Rates of methadone diversion reports increased, on average, 24.3\% per year through 2006 and during 2006-2009 continued to increase, but substantially more slowly (an average of $3.5 \%$ per year); after 2009, methadone diversion rates declined, on average, $12.8 \%$ per year. There was a strong positive correlation between the rate of methadone distribution and the rates of overdose death $(r=0.89, \mathrm{p}<0.05)$ and methadone diversion $(r=0.95, \mathrm{p}<0.05)$.

\footnotetext{
$\dagger^{\dagger}$ http://www.deadiversion.usdoj.gov/nflis/index.html.

${ }^{\S}$ http://surveillance.cancer.gov/joinpoint/.
} 
FIGURE 1. Rates* of methadone-involved overdose deaths, methadone distribution, and methadone diversion ${ }^{\dagger}$ reports United States, 2002-2014§

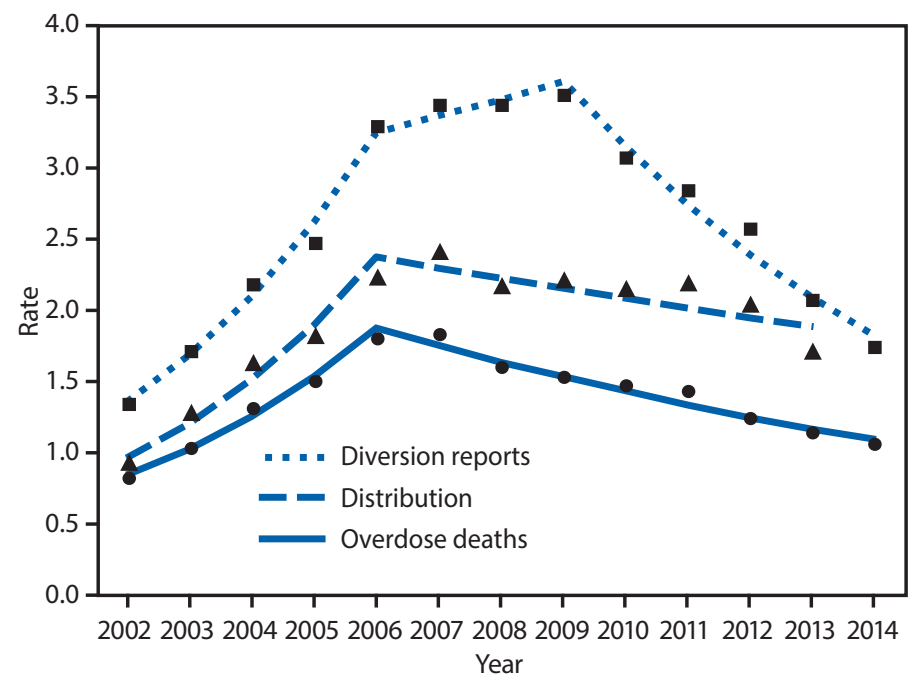

* The rates shown are for the number of methadone-involved overdose deaths per 100,000 population, number of methadone diversion reports per 100,000 population, and number of grams of methadone distributed per 100 population. t The transfer of legally manufactured methadone into illegal markets.

$\S$ Each joinpoint represents a statistically significant change in trend, $\mathrm{p}<0.05$.

In the Northeast, Midwest, and South census regions, the methadone distribution rate peaked in 2006, followed by average annual declines of $2.3 \%, 0.2 \%$, and $5.7 \%$, respectively (Figure 2). The rate of methadone distribution in the West region stabilized during 2006-2011 and then declined, on average, $10.8 \%$ annually during $2011-2013$. The rates of methadone diversion and overdose death within each region followed a similar pattern as methadone distribution.

Males consistently experienced higher overdose death rates than females during 2002-2014 (Table). The overdose death rate in males increased an average of $23.1 \%$ per year during 2002-2006 and then declined an average of $6.5 \%$ per year during 2006-2011, followed by a steeper average annual decline (11.0\% per year) during 2011-2014. Among females, the overdose death rate increased an average of $20.2 \%$ per year during 2002-2006, followed by a more gradual average annual decline $(5.6 \%$ per year) compared with that among males.

The methadone overdose death rate peaked during 2005-2007 among all groups aged $<55$ years. Persons aged 25-54 years had the highest overdose death rates during the study period, and all experienced significant declines after 2006. The largest average annual decline (17.3\%) occurred among persons aged 15-24 years. Among persons aged 55-64 years, the methadone overdose death rate continued to increase during the study period. There was no statistically significant change in the trend among persons aged $\geq 65$ years.

\section{Summary \\ What is already known about this topic?}

Use of the prescription opioid methadone for treatment of pain, rather than for treatment of opioid use disorder, has been identified as an important contributor to the rise in opioid-related overdose deaths. In recent years, a number of actions to reduce the use of methadone for pain treatment have been taken.

What is added by this report?

During 2002-2006, the national distribution rate of methadone increased, on average, $25.1 \%$ per year, methadone-involved drug overdose deaths increased $22.1 \%$ per year, and methadone diversion increased $24.3 \%$ per year. After 2006, methadone distribution declined 3.2\% per year, and methadone-involved overdose deaths declined $6.5 \%$ per year. Rates of methadone diversion continued to increase during 2006-2009, but substantially more slowly, and then declined an average of $12.8 \%$ per year beginning in 2010. By sex, most age groups, race/ethnicity, and U.S. Census region, the methadone overdose death rate peaked during 2005-2007 and declined in subsequent years. Persons aged $25-54$ years had the highest overdose death rates during the study period. There was no significant change in the overdose death rate trend among persons aged $\geq 65$ years, who also had the lowest overdose death rate. Among persons aged 55-64 years, the rate of methadone overdose deaths continued to increase through 2014.

What are the implications for public health practice?

Additional clinical and public health policy changes are needed to further reduce methadone-related harm, especially among persons aged $\geq 55$ years.

The methadone overdose death rate peaked in 2006 among non-Hispanic whites, non-Hispanic blacks, and Hispanics, with average annual declines of $6.6 \%, 4.3 \%$, and $3.9 \%$, respectively, after 2006. Throughout the study period, non-Hispanic whites experienced higher methadone overdose death rates than other racial/ethnic groups.

\section{Discussion}

During 2002-2014, there was a strong positive association between rates of methadone distribution for use in pain treatment and methadone diversion and overdose deaths. The 3,400 reported methadone overdose deaths in 2014 is the lowest number since 2003. With few exceptions, the decline in methadone overdose deaths was seen by sex and across age groups and racial/ethnic populations. Importantly, these declines occurred in the context of more than 100,000 additional persons receiving methadone for the treatment of opioid use disorder during 2002-2013, suggesting that policies targeting methadone use for pain are not affecting access to methadone for treatment of opioid use disorder. 
FIGURE 2. Rates* of methadone-involved overdose deaths, methadone distribution, and methadone diversion ${ }^{\dagger}$ reports, by U.S. Census region - United States, 2002-2014§
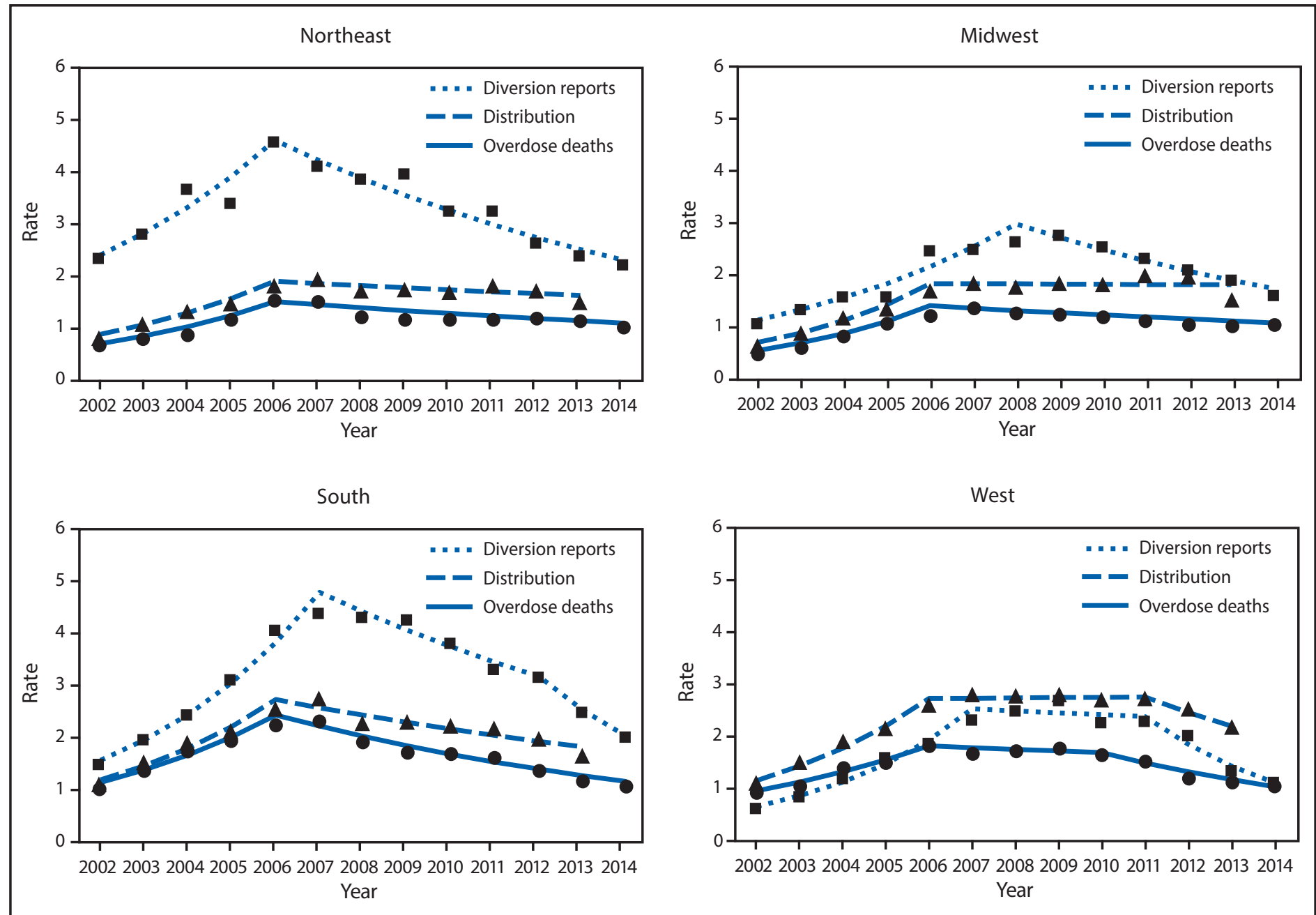

* The rates shown are for the number of methadone-involved overdose deaths per 100,000 population, number of methadone diversion reports per 100,000 population, and number of grams of methadone distributed per 100 population.

† The transfer of legally manufactured methadone into illegal markets.

$\S$ Each joinpoint represents a statistically significant change in trend, $p<0.05$.

The declines identified in this study coincide with actions aimed at reducing methadone use for pain. In 2006, FDA issued warnings about the risks of prescribing methadone for pain. Because methadone has a long and variable half-life, FDA also revised the dosing interval from every $3-4$ hours to every 8-12 hours (2), and in January 2008, DEA and methadone manufacturers agreed to limit the distribution of the largest ( $40 \mathrm{mg}$ ) formulation of methadone to opioid use disorder treatment programs and hospitals. Since that time, professional practice guidelines, medical societies, and government recommendations have targeted reducing the use of methadone for pain $(1,5,6)$. In addition, at least 16 states have removed methadone from

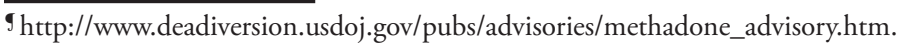

their Medicaid preferred drug list, a step that can substantially reduce the routine use of methadone for pain (3).

Although the findings in this study are encouraging, the persistent methadone-involved overdose death rates found among persons aged $\geq 55$ years, and the more moderate decline among women, as well as continued increases in opioid overdose deaths not involving methadone, which rose from 11,430 deaths in 2002 to 27,488 deaths in 2014 suggest additional opportunities for intervention. In addition, the variation among U.S. Census regions, which reflects the variation in overall opioid prescribing among states ( 7 ), underscores the need for interventions that facilitate evidence-based pain treatment and reduce inappropriate opioid prescribing. The Centers for Medicare \& Medicaid Services recently issued recommendations on best practices for addressing prescription opioid 
TABLE. Number and rate* of methadone overdose deaths, by selected characteristics — United States, 2002-2014

\begin{tabular}{|c|c|c|c|c|c|c|c|c|c|c|c|c|c|c|}
\hline & 2002 & 2003 & 2004 & 2005 & 2006 & 2007 & 2008 & 2009 & 2010 & 2011 & 2012 & 2013 & 2014 & \\
\hline Characteristic & $\begin{array}{l}\text { No. } \\
\text { (rate) }\end{array}$ & $\begin{array}{c}\text { No. } \\
\text { (rate) }\end{array}$ & $\begin{array}{l}\text { No. } \\
\text { (rate) }\end{array}$ & $\begin{array}{l}\text { No. } \\
\text { (rate) }\end{array}$ & $\begin{array}{l}\text { No. } \\
\text { (rate) }\end{array}$ & $\begin{array}{l}\text { No. } \\
\text { (rate) }\end{array}$ & $\begin{array}{l}\text { No. } \\
\text { (rate) }\end{array}$ & $\begin{array}{l}\text { No. } \\
\text { (rate) }\end{array}$ & $\begin{array}{l}\text { No. } \\
\text { (rate) }\end{array}$ & $\begin{array}{l}\text { No. } \\
\text { (rate) }\end{array}$ & $\begin{array}{l}\text { No. } \\
\text { (rate) }\end{array}$ & $\begin{array}{c}\text { No. } \\
\text { (rate) }\end{array}$ & $\begin{array}{l}\text { No. } \\
\text { (rate) }\end{array}$ & $\begin{array}{c}\text { Year of } \\
\text { joinpoint }\end{array}$ \\
\hline Overall & $\begin{array}{l}2,358 \\
(0.82)\end{array}$ & $\begin{array}{l}2,972 \\
(1.03)\end{array}$ & $\begin{array}{l}3,845 \\
(1.31)\end{array}$ & $\begin{array}{l}4,460 \\
(1.50)\end{array}$ & $\begin{array}{l}5,406 \\
(1.80)\end{array}$ & $\begin{array}{l}5,518 \\
(1.83)\end{array}$ & $\begin{array}{l}4,924 \\
(1.60)\end{array}$ & $\begin{array}{l}4,696 \\
(1.53)\end{array}$ & $\begin{array}{l}4,577 \\
(1.47)\end{array}$ & $\begin{array}{l}4,418 \\
(1.43)\end{array}$ & $\begin{array}{l}3,932 \\
(1.24)\end{array}$ & $\begin{array}{l}3,591 \\
(1.14)\end{array}$ & $\begin{array}{l}3,400 \\
(1.06)\end{array}$ & 2006 \\
\hline \multicolumn{15}{|l|}{ Sex } \\
\hline Female & $\begin{array}{c}832 \\
(0.57)\end{array}$ & $\begin{array}{l}1,040 \\
(0.71)\end{array}$ & $\begin{array}{l}1,343 \\
(0.91)\end{array}$ & $\begin{array}{l}1,548 \\
(1.03)\end{array}$ & $\begin{array}{l}1,789 \\
(1.17)\end{array}$ & $\begin{array}{l}1,921 \\
(1.26)\end{array}$ & $\begin{array}{l}1,723 \\
(1.10)\end{array}$ & $\begin{array}{l}1,662 \\
(1.06)\end{array}$ & $\begin{array}{l}1,646 \\
(1.05)\end{array}$ & $\begin{array}{l}1,675 \\
(1.05)\end{array}$ & $\begin{array}{l}1,480 \\
(0.93)\end{array}$ & $\begin{array}{l}1,457 \\
(0.91)\end{array}$ & $\begin{array}{l}1,391 \\
(0.87)\end{array}$ & 2006 \\
\hline Male & $\begin{array}{l}1,526 \\
(1.05)\end{array}$ & $\begin{array}{l}1,932 \\
(1.32)\end{array}$ & $\begin{array}{l}2,502 \\
(1.71)\end{array}$ & $\begin{array}{l}2,912 \\
(1.97)\end{array}$ & $\begin{array}{l}3,617 \\
(2.42)\end{array}$ & $\begin{array}{l}3,597 \\
(2.40)\end{array}$ & $\begin{array}{l}3,201 \\
(2.12)\end{array}$ & $\begin{array}{l}3,034 \\
(1.99)\end{array}$ & $\begin{array}{l}2,931 \\
(1.91)\end{array}$ & $\begin{array}{l}2,743 \\
(1.77)\end{array}$ & $\begin{array}{l}2,452 \\
(1.57)\end{array}$ & $\begin{array}{l}2,134 \\
(1.35)\end{array}$ & $\begin{array}{l}2,009 \\
(1.27)\end{array}$ & 2006, 2011 \\
\hline \multicolumn{15}{|l|}{ Age group (yrs) } \\
\hline $15-24$ & $\begin{array}{c}298 \\
(0.73)\end{array}$ & $\begin{array}{c}442 \\
(1.07)\end{array}$ & $\begin{array}{c}597 \\
(1.42)\end{array}$ & $\begin{array}{c}603 \\
(1.42)\end{array}$ & $\begin{array}{c}811 \\
(1.89)\end{array}$ & $\begin{array}{c}861 \\
(2.00)\end{array}$ & $\begin{array}{c}699 \\
(1.61)\end{array}$ & $\begin{array}{c}624 \\
(1.43)\end{array}$ & $\begin{array}{c}564 \\
(1.29)\end{array}$ & $\begin{array}{c}477 \\
(1.09)\end{array}$ & $\begin{array}{c}341 \\
(0.78)\end{array}$ & $\begin{array}{c}274 \\
(0.62)\end{array}$ & $\begin{array}{c}241 \\
(0.55)\end{array}$ & 2007 \\
\hline $25-34$ & $\begin{array}{c}461 \\
(1.17)\end{array}$ & $\begin{array}{c}540 \\
(1.38)\end{array}$ & $\begin{array}{c}814 \\
(2.07)\end{array}$ & $\begin{array}{c}979 \\
(2.49)\end{array}$ & $\begin{array}{l}1,238 \\
(3.14)\end{array}$ & $\begin{array}{l}1,305 \\
(3.29)\end{array}$ & $\begin{array}{l}1,145 \\
(2.85)\end{array}$ & $\begin{array}{l}1,096 \\
(2.69)\end{array}$ & $\begin{array}{l}1,150 \\
(2.80)\end{array}$ & $\begin{array}{l}1,094 \\
(2.62)\end{array}$ & $\begin{array}{c}989 \\
(2.34)\end{array}$ & $\begin{array}{c}855 \\
(2.00)\end{array}$ & $\begin{array}{c}796 \\
(1.83)\end{array}$ & 2006,2011 \\
\hline $35-44$ & $\begin{array}{c}794 \\
(1.78)\end{array}$ & $\begin{array}{c}965 \\
(2.19)\end{array}$ & $\begin{array}{l}1,142 \\
(2.61)\end{array}$ & $\begin{array}{l}1,217 \\
(2.80)\end{array}$ & $\begin{array}{l}1,394 \\
(3.22)\end{array}$ & $\begin{array}{l}1,305 \\
(3.05)\end{array}$ & $\begin{array}{l}1,102 \\
(2.61)\end{array}$ & $\begin{array}{l}1,036 \\
(2.50)\end{array}$ & $\begin{array}{c}982 \\
(2.39)\end{array}$ & $\begin{array}{l}1,005 \\
(2.47)\end{array}$ & $\begin{array}{c}906 \\
(2.24)\end{array}$ & $\begin{array}{c}842 \\
(2.08)\end{array}$ & $\begin{array}{c}768 \\
(1.90)\end{array}$ & 2006 \\
\hline $45-54$ & $\begin{array}{c}662 \\
(1.66)\end{array}$ & $\begin{array}{c}841 \\
(2.06)\end{array}$ & $\begin{array}{l}1,024 \\
(2.46)\end{array}$ & $\begin{array}{l}1,290 \\
(3.04)\end{array}$ & $\begin{array}{l}1,521 \\
(3.51)\end{array}$ & $\begin{array}{l}1,525 \\
(3.47)\end{array}$ & $\begin{array}{l}1,472 \\
(3.31)\end{array}$ & $\begin{array}{l}1,332 \\
(2.97)\end{array}$ & $\begin{array}{l}1,245 \\
(2.77)\end{array}$ & $\begin{array}{l}1,194 \\
(2.67)\end{array}$ & $\begin{array}{l}1,017 \\
(2.30)\end{array}$ & $\begin{array}{c}898 \\
(2.05)\end{array}$ & $\begin{array}{c}854 \\
(1.97)\end{array}$ & 2006 \\
\hline $55-64$ & $\begin{array}{c}101 \\
(0.38)\end{array}$ & $\begin{array}{c}151 \\
(0.54)\end{array}$ & $\begin{array}{c}209 \\
(0.71)\end{array}$ & $\begin{array}{c}300 \\
(0.98)\end{array}$ & $\begin{array}{c}351 \\
(1.10)\end{array}$ & $\begin{array}{c}450 \\
(1.36)\end{array}$ & $\begin{array}{c}413 \\
(1.21)\end{array}$ & $\begin{array}{c}523 \\
(1.48)\end{array}$ & $\begin{array}{c}558 \\
(1.53)\end{array}$ & $\begin{array}{c}564 \\
(1.48)\end{array}$ & $\begin{array}{c}590 \\
(1.53)\end{array}$ & $\begin{array}{c}594 \\
(1.51)\end{array}$ & $\begin{array}{c}629 \\
(1.57)\end{array}$ & 2007 \\
\hline$\geq 65$ & $\begin{array}{c}26 \\
(0.07)\end{array}$ & - & $\begin{array}{c}36 \\
(1.10)\end{array}$ & $\begin{array}{c}50 \\
(0.14)\end{array}$ & $\begin{array}{c}63 \\
(0.17)\end{array}$ & $\begin{array}{c}45 \\
(0.12)\end{array}$ & $\begin{array}{c}59 \\
(0.15)\end{array}$ & $\begin{array}{c}69 \\
(0.17)\end{array}$ & $\begin{array}{c}51 \\
(0.13)\end{array}$ & $\begin{array}{c}70 \\
(0.17)\end{array}$ & $\begin{array}{c}75 \\
(0.17)\end{array}$ & $\begin{array}{c}114 \\
(0.26)\end{array}$ & $\begin{array}{c}98 \\
(0.21)\end{array}$ & NA \\
\hline \multicolumn{15}{|l|}{ Race/Ethnicity } \\
\hline White, non-Hispanic & $\begin{array}{l}2,058 \\
(1.05)\end{array}$ & $\begin{array}{l}2,623 \\
(1.33)\end{array}$ & $\begin{array}{l}3,377 \\
(1.73)\end{array}$ & $\begin{array}{l}3,895 \\
(2.00)\end{array}$ & $\begin{array}{l}4,745 \\
(2.45)\end{array}$ & $\begin{array}{l}4,840 \\
(2.46)\end{array}$ & $\begin{array}{l}4,301 \\
(2.20)\end{array}$ & $\begin{array}{l}4,062 \\
(2.08)\end{array}$ & $\begin{array}{l}3,943 \\
(1.98)\end{array}$ & $\begin{array}{l}3,769 \\
(1.93)\end{array}$ & $\begin{array}{l}3,332 \\
(1.70)\end{array}$ & $\begin{array}{l}3,012 \\
(1.54)\end{array}$ & $\begin{array}{l}2,845 \\
(1.43)\end{array}$ & 2006 \\
\hline Black, non-Hispanic & $\begin{array}{c}141 \\
(0.42)\end{array}$ & $\begin{array}{c}149 \\
(0.43)\end{array}$ & $\begin{array}{c}216 \\
(0.60)\end{array}$ & $\begin{array}{c}257 \\
(0.70)\end{array}$ & $\begin{array}{c}315 \\
(0.87)\end{array}$ & $\begin{array}{c}312 \\
(0.81)\end{array}$ & $\begin{array}{c}245 \\
(0.63)\end{array}$ & $\begin{array}{c}266 \\
(0.68)\end{array}$ & $\begin{array}{c}254 \\
(0.62)\end{array}$ & $\begin{array}{c}278 \\
(0.68)\end{array}$ & $\begin{array}{c}239 \\
(0.58)\end{array}$ & $\begin{array}{c}239 \\
(0.59)\end{array}$ & $\begin{array}{c}256 \\
(0.63)\end{array}$ & 2006 \\
\hline Other, non-Hispanic & $\begin{array}{c}33 \\
(0.21)\end{array}$ & $\begin{array}{c}39 \\
(0.23)\end{array}$ & $\begin{array}{c}59 \\
(0.34)\end{array}$ & $\begin{array}{c}74 \\
(0.42)\end{array}$ & $\begin{array}{c}81 \\
(0.46)\end{array}$ & $\begin{array}{c}82 \\
(0.43)\end{array}$ & $\begin{array}{c}90 \\
(0.45)\end{array}$ & $\begin{array}{c}97 \\
(0.49)\end{array}$ & $\begin{array}{c}88 \\
(0.43)\end{array}$ & $\begin{array}{c}91 \\
(0.44)\end{array}$ & $\begin{array}{c}86 \\
(0.40)\end{array}$ & $\begin{array}{c}71 \\
(0.33)\end{array}$ & $\begin{array}{c}50 \\
(0.24)\end{array}$ & 2005,2011 \\
\hline Hispanic & $\begin{array}{c}109 \\
(0.32)\end{array}$ & $\begin{array}{c}151 \\
(0.43)\end{array}$ & $\begin{array}{c}175 \\
(0.46)\end{array}$ & $\begin{array}{c}215 \\
(0.55)\end{array}$ & $\begin{array}{c}246 \\
(0.62)\end{array}$ & $\begin{array}{c}269 \\
(0.61)\end{array}$ & $\begin{array}{c}268 \\
(0.60)\end{array}$ & $\begin{array}{c}243 \\
(0.52)\end{array}$ & $\begin{array}{c}274 \\
(0.56)\end{array}$ & $\begin{array}{c}250 \\
(0.51)\end{array}$ & $\begin{array}{c}241 \\
(0.47)\end{array}$ & $\begin{array}{c}248 \\
(0.50)\end{array}$ & $\begin{array}{c}228 \\
(0.46)\end{array}$ & 2006 \\
\hline
\end{tabular}

Abbreviation: $\mathrm{NA}=$ not applicable.

* Rates (deaths per 100,000 population) are presented as age-adjusted rates, with the exception of rates by age group.

${ }^{\dagger}$ Each joinpoint represents a statistically significant change in trend, $p<0.05$.

overdose, focusing on steps insurers can take to reduce harms associated with methadone use for pain (8). In addition, CDC recommends that methadone not be the first choice for a long-acting opioid and that only clinicians who are familiar with methadone's unique risk profile and are prepared to educate and closely monitor their patients consider prescribing methadone for pain (9). Finally, health systems should consider the use of coordinated care plans to optimize evidence-based care. Coordinated care plans structure and coordinate care by increasing precautions for patients taking high dosages, codifying treatment agreements with patients, monitoring patients with urine drug tests and prescription drug monitoring program checks, and avoiding prescribing opioids in conjunction with benzodiazepines; coordinated care plans have been shown to reduce risk factors for opioid-related harm (10), and might be especially effective with older patients.

The findings in this report are subject to at least four limitations. First, vital statistics underestimate the number of overdose deaths from specific drugs because the type of drug is not specified on approximately $20 \%-25 \%$ of death certificates. Second, some deaths might have resulted from methadone provided in take-home doses by opioid use disorder treatment programs. Third, although methadone distributed to opioid treatment programs was excluded from the analysis, it is possible that some of the methadone distributed to hospitals, which was included in the analysis, might have been used in the short-term treatment of opioid use disorder. Finally, National Forensic Laboratory Information System estimates of methadone diversion might be subject to variation associated with sample estimates, including nonresponse bias. However, the National Forensic Laboratory Information System estimation methodology was consistent across the study period.

Significant declines in methadone overdose deaths and diversion reports strongly correlate with reduced amounts of methadone used for pain. Insurer strategies and clinical practice guidelines that place parameters and structured monitoring on the use of methadone for pain are promising approaches and should be studied further. Importantly, the declines found in this study appear to be appropriately linked to the use of methadone for pain and not impeding access to methadone for the treatment of opioid use disorder. 
${ }^{1}$ Office of the Assistant Secretary for Planning and Evaluation, U.S. Department of Health and Human Services; ${ }^{2}$ Division of Unintentional Injury Prevention, National Center for Injury Prevention and Control, CDC; ${ }^{3}$ Division of Analysis, Research, and Practice Integration, National Center for Injury Prevention and Control, CDC.

Corresponding author: Christopher M. Jones, Christopher.Jones@hhs.gov, 202-690-7287.

\section{References}

1. Paulozzi LJ, Mack KA, Jones CM. Vital signs: risk for overdose from methadone used for pain relief-United States, 1999-2010. MMWR Morb Mortal Wkly Rep 2012;61:493-7.

2. Food and Drug Administration. Public health advisory: methadone use for pain control might result in death and life-threatening changes in breathing and heartbeat. Rockville, MD: Food and Drug Administration; 2006. http://www.fda.gov/Drugs/DrugSafety/ PostmarketDrugSafetyInformationforPatientsandProviders/ucm 124346.htm

3. The Pew Charitable Trusts. Most states list deadly drug methadone as a "preferred drug." Philadelphia, PA: The Pew Charitable Trusts; 2015. http:// www.pewtrusts.org/en/research-and-analysis/blogs/stateline/2015/4/23/ most-states-list-deadly-methadone-as-a-preferred-drug

4. CDC. WONDER [Database]. Atlanta, GA: US Department of Health and Human Services, CDC; 2014. http://wonder.cdc.gov
5. Nuckols TK, Anderson L, Popescu I, et al. Opioid prescribing: a systematic review and critical appraisal of guidelines for chronic pain. Ann Intern Med 2014;160:38-47.

6. American Academy of Pain Medicine. The evidence against methadone as a "preferred" analgesic. Chicago, IL: American Academy of Pain Medicine; 2014. http://www.painmed.org/files/the-evidence-againstmethadone-as-a-preferred-analgesic.pdf

7. Paulozzi LJ, Mack KA, Hockenberry JM. Vital signs: variation among states in prescribing of opioid pain relievers and benzodiazepines-United States, 2012. MMWR Morb Mortal Wkly Rep 2014;63:563-8.

8. Centers for Medicare \& Medicaid Services. CMCS informational bulletin: best practices for addressing prescription opioid overdoses, misuse, and addiction. Baltimore, MD: US Department of Health and Human Services, Centers for Medicare \& Medicaid Services; 2016. https://www.medicaid.gov/federal-policy-guidance/downloads/cib-0202-16.pdf

9. Dowell D, Haegerich TM, Chou R. CDC guideline for prescribing opioids for chronic pain-United States, 2016. MMWR Recomm Rep 2016;65(No. RR-1). http://dx.doi.org/10.15585/mmwr.rr6501e1

10. Von Korff M, Dublin S, Walker RL, et al. The impact of opioid risk reduction initiatives on high-dose opioid prescribing for patients on chronic opioid therapy. J Pain 2016;17:101-10. http://dx.doi. org/10.1016/j.jpain.2015.10.002 